\title{
Studies of the Mechanism of the Antidiarrheal
}

\section{Effect of Codeine}

\author{
Lawrence R. Schiller, Glenn R. Davis, Carol A. Santa Ana, \\ STEPhEN G. MorawSKi, and John S. Fordtran, Department of Internal \\ Medicine, Baylor University Medical Center, Dallas, Texas 75246; Veterans \\ Administration Medical Center, Dallas, Texas 75216
}

\begin{abstract}
A B S T R A C T To determine whether the antidiarrheal action of opiate drugs in humans is due to enhanced intestinal absorption rates, as suggested by recent experiments in animals, or is due to altered intestinal motility, as traditionally thought, we studied the effect of therapeutic doses of codeine on experimental diarrhea and on the rate of intestinal absorption of water and electrolytes in normal human subjects. Our results show that codeine (30-60 mg i.m.) markedly reduced stool volume during experimental diarrhea induced by rapid intragastric infusion of a balanced electrolyte solution. There was, however, no evidence that codeine stimulated the rate of intestinal absorption in the gut as a whole or in any segment of the gastrointestinal tract, either in the basal state or when absorption rates were reduced by intravenous infusion of vasoactive intestinal polypeptide. We also measured segmental transit times to determine whether and where codeine delayed the passage of fluid through the intestine. Codeine caused a marked slowing of fluid movement through the jejunum, but had no effect on the movement of fluid through the ileum or colon. In other studies, we found that the opiate antagonist naloxone did not significantly affect water or electrolyte absorption rates in the jejunum or ileum. We conclude (a) that therapeutic doses of codeine increase net intestinal absorption (and thereby reduce stool volume) by increasing the contact time of luminal fluid with mucosal cells, not by increasing the rate of absorption by the mucosal cells; and $(b)$ that endogenous opiates do not regulate intestinal absorption in humans.
\end{abstract}

This study was presented in part at the $82 \mathrm{nd}$ Meeting of the American Gastroenterological Association, May 1981, New York, and appeared in abstract form in Gastroenterology. 80: 1275 .

Received for publication 15 June 1981 and in revised form 3 August 1982.

\section{INTRODUCTION}

Recent in vitro (1-4) and in vivo (5-9) studies in laboratory animals suggest that various endogenous and exogenous opiates stimulate the rate of water and electrolyte absorption across intestinal mucosa. These results suggest that opiate drugs reduce stool volume in diarrheal diseases by directly stimulating mucosal cell absorption rates rather than by affecting intestinal motility (1-10), as classically taught (11). Furthermore, in one of these experiments, an opiate antagonist (naloxone) reduced absorption in some preparations even when an exogenous opiate had not been administered (3), which suggests that endogenous opiates may regulate mucosal transport rates under normal physiological circumstances.

Because of differences in species, in methods, and in the types and doses of opiates, it is impossible to apply these results and conclusions to human physiology and disease. We therefore conducted a series of experiments in normal human subjects to evaluate whether therapeutic doses of codeine reduce stool volume in an experimental diarrhea model, and, if so, whether this antidiarrheal effect is mediated by an effect on mucosal cell absorption rates or by an effect on motility. We also measured the effect of codeine on intestinal absorption rates under conditions in which absorption had been reduced by intravenous infusion of vasoactive intestinal polypeptide (VIP). ${ }^{1}$ Codeine was selected as the opiate to be tested because previous studies have indicated that codeine is a potent antidiarrheal agent (11-13), and it can be injected parenterally. In addition to studies with codeine, we also investigated whether the opiate antagonist nal-

\footnotetext{
${ }^{1}$ Abbreviations used in this paper: BSP, sulfobromophthalein; PD, potential difference; PEG, polyethylene glycol; VIP, vasoactive intestinal polypeptide.
} 
oxone alters intestinal absorption rates in the jejunum and ileum of normal subjects in vivo.

\section{METHODS}

\section{Subjects}

28 individuals ( 17 males, 11 females), ranging in age from 21 to $37 \mathrm{yr}$ (mean, $27 \pm 1 \mathrm{yr}$ ) participated in these studies after giving informed written consent. The consent forms and study protocols were approved by an institutional $\mathrm{Hu}$ man Research Review Committee on 1 July 1979.

\section{Experimental diarrhea produced by intragastric infusion of balanced electrolyte solution}

Series A. After an overnight fast, five subjects swallowed a single-lumen polyvinyl tube, and a balanced electrolyte solution $\left(100 \mathrm{mM} \mathrm{NaCl}, 40 \mathrm{mM} \mathrm{NaHCO}{ }_{3}, 4 \mathrm{mM} \mathrm{KCl}\right.$, gassed with $95 \% \mathrm{O}_{2}$ and $5 \% \mathrm{CO}_{2}$ ), containing $2 \mathrm{~g}$ /liter polyethylene glycol (PEG, mol wt 3,000-3,700) as a nonabsorbable marker, was infused into the stomach at a rate of $30 \mathrm{ml} /$ min. $10 \mathrm{~min}$ after starting the infusion, $200 \mathrm{mg}$ of sulfobromophthalein (BSP) was injected into the stomach. Watery diarrhea developed after 1-2 h, and when this occurred, a rectal tube was placed to collect all stool.

$1 \mathrm{~h}$ after BSP was no longer detectable in stool (indicating that the gut had been completely washed out), on average $192 \pm 18 \mathrm{~min}$ after starting the infusion, $30 \mathrm{mg}$ codeine phosphate or placebo was injected intramuscularly, and $30 \mathrm{~min}$ later the intragastric infusion was stopped. Rectal effluent was collected via the rectal tube in 10-min samples for $4 \mathrm{~h}$ after injection of codeine or placebo. The rectal tube was then removed, but any stool produced during the remainder of the 24-h period was collected. Most subjects produced no stool from 4 to $24 \mathrm{~h}$ after injection, and the largest collection was $18 \mathrm{~g}$. On a separate day, the study was repeated and the other agent (placebo or codeine) was injected intramuscularly.

Preliminary paired studies in three subjects in whom a PEG-free solution was used to lavage the gut $1 \mathrm{~h}$ after injection of codeine or placebo indicated that PEG recovery averaged $100 \%$ (range, $92-105 \%$ ) and was unaffected by injection of codeine.

Series B. Five other subjects participated in a second series of studies. They were prepared the evening before each experiment by oral ingestion of 4 liter of a nonabsorbable gastrointestinal lavage solution containing $\mathrm{Na}_{2} \mathrm{SO}_{4}$ and PEG (14), followed by 2 liter of a balanced electrolyte solution without PEG to insure that the colon was free of the nonabsorbable solution by the next morning, when the test was started. A sample of the final rectal effluent after the lavage was tested for PEG and was negative in every case.

After fasting overnight, each subject swallowed a singlelumen polyvinyl tube, and a rectal tube was placed with its tip $17 \mathrm{~cm}$ from the anal verge. In no case was fluid recovered from the rectum. $30 \mathrm{mg}$ codeine or placebo was then injected intramuscularly and balanced electrolyte solution identical to that used in the series A experiments was infused intragastrically at a rate of $30 \mathrm{ml} / \mathrm{min}$ for $90 \mathrm{~min}$ (total amount infused, $2,700 \mathrm{ml}$ ). The intramuscular injection of codeine or placebo was repeated $1 \mathrm{~h}$ after the first injection. Rectal effluent was collected for $6 \mathrm{~h}$ after the first injection. On another day, the study was repeated and the other agent (placebo or codeine) was injected intramuscularly.

Series $C$. Five subjects were prepared and intubated as in series B. Balanced electrolyte solution (identical to that used in series A and B) was infused intragastrically at 30 $\mathrm{ml} / \mathrm{min}$ for $8 \mathrm{~h}$. Rectal effluent was collected in 30-min samples. $30 \mathrm{mg}$ codeine was injected intramuscularly 4 and 5 $h$ after the infusion was started. PEG concentrations were measured on each 30-min stool collection.

To illustrate the effects of an increased rate of water absorption in this experimental model, an additional experiment was performed on another day in four of these subjects and in one other subject. Instead of codeine, the test solution was switched to a glucose electrolyte solution $(100 \mathrm{mM}$ glucose, $40 \mathrm{mM} \mathrm{NaCl}, 40 \mathrm{mM} \mathrm{NaHCO}, 4 \mathrm{mM} \mathrm{KCl}$, gassed with $95 \% \mathrm{O}_{2}$ and $5 \% \mathrm{CO}_{2}$ and $2 \mathrm{~g} /$ liter PEG) after $5 \mathrm{~h}$ of infusion of balanced electrolyte solution. Intraluminal glucose stimulates the rate of water absorption by mucosal cells.

\section{Experimental diarrhea produced by colonic infusion of balanced electrolyte solution}

Each of five subjects was studied on two test days. On one day, placebo was given, and the other day codeine was given. Subjects were prepared on the evening before each study day as in Series B. On the next morning, a rectal tube was placed with its tip $17 \mathrm{~cm}$ from the anal verge and $1,500 \mathrm{ml}$ of a balanced electrolyte solution (of the same composition as in the intragastric infusion studies) was infused through the rectal tube over a $25-\mathrm{min}$ period. This volume was selected because it is the approximate volume of barium suspension required to fill the colon in diagnostic radiography without overfilling or inducing ileal reflux. ${ }^{2}$ The tube was then clamped and $30 \mathrm{mg}$ codeine or placebo was given intramuscularly. $20 \mathrm{~min}$ later, the rectal tube was unclamped and rectal effluent was collected in 10-min samples for 100 min. The rectal tube was then removed and any stool produced during the remainder of a $24-\mathrm{h}$ period was collected.

\section{Segmental intestinal perfusion studies}

Segmental intestinal perfusion was used to measure transit times and intestinal absorption rates. Subjects were intubated with a triple-lumen polyvinyl tube as previously described $(15,16)$. This tube has an infusion port and two collection sites $10 \mathrm{~cm}$ (proximal) and $40 \mathrm{~cm}$ (distal) beyond the inf usion port. In the small bowel studies, this allowed for a $10-\mathrm{cm}$ mixing segment and a $30-\mathrm{cm}$ test segment. For studies of colonic absorption, the distal collecting site was situated in the cecum, and test solution was infused into the distal ileum through the proximal collecting site. Samples of luminal fluid were collected from the cecum and from an additional tube placed within the rectum. This arrangement allowed the test segment to include the entire colon. The correct positioning of the triple-lumen tube in all studies was confirmed by fluoroscopy.

Balanced electrolyte solution identical to that used in the experimental diarrhea model (except for the addition of 10 $\mathrm{mM}$ xylose as an absorbable nonelectrolyte in the jejunal and ileal studies) was perfused at a rate of $10 \mathrm{ml} / \mathrm{min}$ (jejunum and ileum) or $20 \mathrm{ml} / \mathrm{min}$ (colon)

After a $30-\mathrm{min}$ (jejunum and ileum) or 60-min (colon)

\footnotetext{
${ }^{2}$ Personal communication, Dr. Herbert Smith.
} 
equilibration period, a $1-\mathrm{ml}$ bolus of fluid containing $200 \mathrm{mg}$ BSP was injected through the infusion site, and samples were obtained by continuous aspiration from both collection ports at a rate of $7 \mathrm{ml}$ (the dead space of the tube) every $3 \mathrm{~min}$ until the BSP had cleared the distal collection site. BSP concentrations were measured in each sample, and mean transit time between the proximal and distal collecting sites was calculated, as previously described (17). Flow rates at the proximal and distal collecting sites were calculated from PEG concentrations by standard equations (18). The volume of the test segment was calculated by multiplying the mean flow rate (the average of the flow rates at the proximal and distal collecting sites) by the transit time through the test segment (17).

Intestinal absorption rates were measured during a subsequent 1-h (jejunum and ileum) or 2-h (colon) period, during which samples were aspirated from both collecting sites at a rate of $1.5 \mathrm{ml} / \mathrm{min}$. Calculation of absorption rates was made as previously described $(15,16,18)$. After measurement during a control period, codeine or naloxone was given as described below, and the equilibration period, transit time measurement, and sampling periods were repeated. In the small bowel steady-state experiments, potential difference (PD) was measured between a subcutaneous reference electrode in the forearm and the flowing electrolyte solution being pumped through the infusion port of the triple-lumen tube (19).

\section{Drugs}

Codeine phosphate injection U.S.P. (Knoll Pharmaceutical Co., Whippany, $\mathrm{NJ}$ ) was administered intramuscularly in doses of $30 \mathrm{mg}$. During segmental intestinal perfusion studies, additional 10-mg doses were injected hourly to maintain blood levels. Total codeine doses were between 30 and 60 $\mathrm{mg}$, and thus corresponded to a large therapeutic dose (11). In some studies, porcine VIP (Gastrointestinal Hormone Research Unit, Karolinska Institutet, Stockholm, Sweden) was infused intravenously at a rate of $400 \mathrm{pmol} / \mathrm{kg}$ per h (see Results). This dose has been shown to decrease water absorption in the human jejunum by $80 \%$ (20). In other studies, naloxone hydrochloride (Narcan, Endo Laboratories, Inc., Garden City, NY) was infused at a rate of $40 \mu \mathrm{g} / \mathrm{kg}$ per $h$ (see Results). This dose has been shown to modify physiological processes in the human gastrointestinal tract (i.e., it reduces basal and amino acid meal-stimulated gastric acid secretion [21]), and is slightly greater than a dose that abolishes the effect of $8 \mathrm{mg}$ loperamide on gastric secretion (22). Bacteriostatic saline for injection was used for control injections. When codeine or saline (control) were administered on separate days, the order of injection was randomized.

\section{Analysis of samples, calculations, and statistics}

Samples were analyzed for electrolyte concentrations, PEG, BSP, and xylose by previously published methods (14$20,23,24)$, and net water and electrolyte absorption was calculated with nonabsorbable marker equations $(16,18)$. Statistical significance was determined by Wilcoxon's signed rank test for matched pairs (when pair differences were not normally distributed) or by two-tailed $t$ tests (when pair differences were normally distributed), with each subject serving as his or her own control (25). $P$ values of $\leq 0.05$ were taken to be statistically significant.

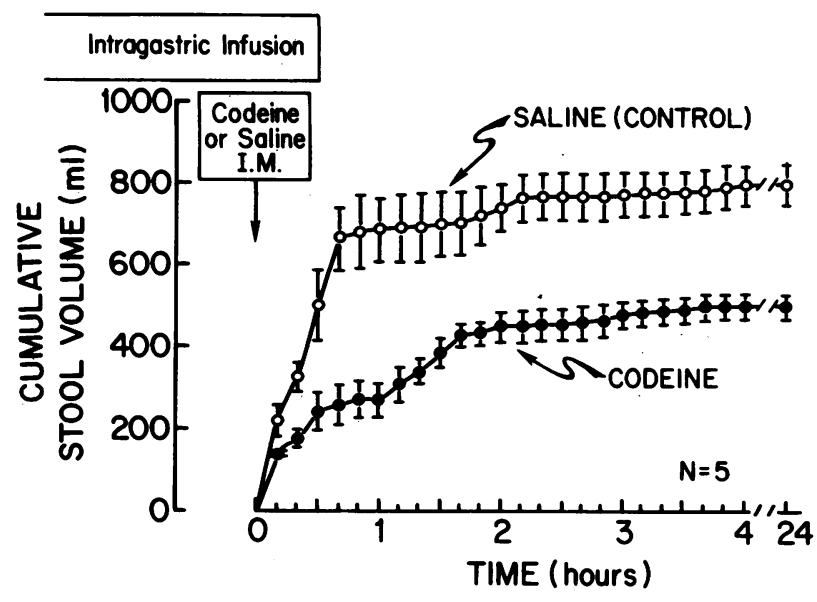

Figure 1 Effect of codeine on experimental diarrhea: Series A experiments. After intragastric infusion of a balanced electrolyte solution resulted in watery diarrhea, $30 \mathrm{mg}$ codeine or saline as a control was injected intramuscularly at $0 \mathrm{~h}$. Intragastric infusion was terminated $0.5 \mathrm{~h}$ later. $\mathrm{Cu}$ mulative stool volume (mean $\pm S E$ ) is plotted. Statistically significant differences by paired $t$ test $(P<0.05)$ were present at $20 \mathrm{~min}$ and from $40 \mathrm{~min}$ to $24 \mathrm{~h}$.

\section{RESULTS}

Effects of codeine on experimental diarrhea produced by intragastric infusion of balanced electrolyte solution. As shown in Fig. 1, injection of $30 \mathrm{mg}$ codeine promptly reduced stool volume in the Series A experiments. Cumulative stool volume after codeine remained significantly less than control for up to $24 \mathrm{~h}$ after injection $(802 \pm 50 \mathrm{ml}$ vs. $499 \pm 28 \mathrm{ml}$, $P<0.02$ ). Since there was no delayed appearance of diarrhea, this indicates that codeine increased net intestinal absorption of the infused electrolyte solution. To determine whether this increased net absorption was due to an increased rate of absorption by mucosal cells (as suggested by the animal studies discussed in the Introduction) or was due to an increase in the time available for absorption (as would occur if codeine altered intestinal motility), we examined stool PEG marker concentrations at a time when stool volumes were reduced by codeine. If stool volume were reduced because of an increased rate of water absorption throughout the intestine, stool PEG concentration would be greater with codeine as soon as an effect on stool volume was apparent. On the other hand, if stool volume were reduced because the passage of fluid through the gastrointestinal tract was slowed, stool PEG concentrations would not be any different with codeine until well after stool volume had decreased.

This concept must be fully appreciated in order to understand the results that follow. For example, if rectal effluent was reduced in half because of increased water absorption by mucosal cells, PEG concentration 
in the effluent would double. Since enhanced water absorption is the primary event, an increase in effluent PEG concentration would be noted as soon as effluent volume was reduced. On the other hand, if rectal effluent volume was reduced in half because of retention of fluid within the gut lumen (reduced delivery of fluid to the rectum), no increase in effluent PEG concentration would be noted initially. The comcentration of PEG in luminal fluid proximal to the rectum would eventually rise as water absorption continued because of prolonged contact of retained fluid with absorbing mucosal cells; but only hours to days later would this be reflected by higher PEG concentrations in rectal effluent or stool.

Table I (Series A) shows the stool PEG concentration during the first hour, a time when the effect of codeine was most pronounced. Since the PEG concentration was no different with or without codeine, less stool was produced during the first hour after codeine because of delayed passage of fluid through the gut, and not because of an increased rate of intestinal absorption by mucosal cells.

In the series B experiments, in which a larger total dose of codeine $(60 \mathrm{mg})$ and a fixed volume of fluid was infused into the stomach, findings were similar. As shown in Fig. 2, codeine delayed the onset of passage of stool and resulted in significantly less cumulative stool volume $(1,048 \pm 111 \mathrm{ml}$ with intramuscular saline vs. $633 \pm 126 \mathrm{ml}$ with intramuscular codeine,

\section{TABLE I}

Mean Stool Volume and PEG Concentration and Output after Intramuscular Injection of Codeine or Placebo in Subjects with Experimental Diarrhea Produced by Intragastric Infusion of Balanced Electrolyte Solution ${ }^{\circ}$

\begin{tabular}{lccr}
\hline & & $\begin{array}{c}\text { PEG } \\
\text { concentration }\end{array}$ & PEG output \\
\hline & $m l$ & $m g / d l$ & $g$ \\
Series A $\downarrow$ & & & \\
Placebo & $688 \pm 78$ & $359 \pm 27$ & $2.4 \pm 0.1$ \\
Codeine & $274 \pm 37$ & $366 \pm 25$ & $1.0 \pm 0.2$ \\
$P$ value & $<0.05$ & NS & $<0.02$ \\
Series B $\$$ & & & \\
Placebo & $968 \pm 120$ & $320 \pm 20$ & $3.1 \pm 0.4$ \\
Codeine & $407 \pm 134$ & $324 \pm 18$ & $1.4 \pm 0.5$ \\
$P$ value & $<0.025$ & NS & 0.05 \\
\hline
\end{tabular}

NS indicates that the difference between placebo and codeine is not statistically significant $(P>0.05)$.

- Values are mean \pm SE.

I $1 \mathrm{~h}$ after injection of placebo or codeine (total codeine dose 30 $\mathrm{mg}, n=5)$.

$\$ 2 \mathrm{~h}$ after initial injection of placebo or codeine (total codeine dose $60 \mathrm{mg}, n=5$ ).

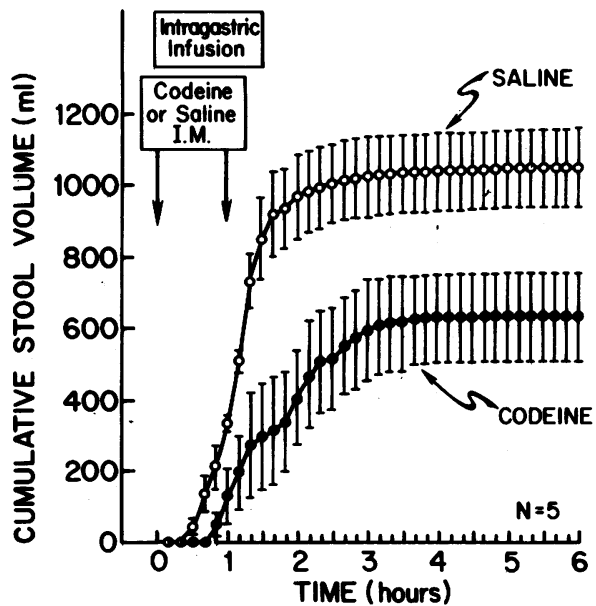

Figure 2 Effect of codeine on experimental diarrhea: Series $B$ experiments. After intramuscular injection of saline (control) or $30 \mathrm{mg}$ codeine, $2,700 \mathrm{ml}$ of balanced electrolyte solution was infused intragastrically over $90 \mathrm{~min}$. A second injection of saline or $30 \mathrm{mg}$ codeine was given $1 \mathrm{~h}$ after the first. Cumulative stool volume (mean $\pm S E$ ) is plotted. Statistically significant differences by paired $t$ test $(P<0.05)$ were present at $50 \mathrm{~min}$ and $70 \mathrm{~min}$ and from 1.5 to $6 \mathrm{~h}$.

$P<0.05$ ). During the first $2 \mathrm{~h}$, when the difference between stool volumes after placebo and codeine injections was greatest, stool PEG concentrations were similar with and without codeine (Table I, series B), which again suggests that less stool was produced after codeine because of delayed passage of fluid through the gut rather than because of delayed passage of fluid through the gut rather than because of an enhanced rate of intestinal absorption by mucosal cells.

Both the series A and series B experiments examined the effect of codeine on nonsteady-state experimental diarrhea models. In series A, the nonsteady state was created by abruptly stopping the intragastric infusion 30 min after codeine, whereas in series $B$, a bolus of $2,700 \mathrm{ml}$ was infused over a 90 -min period after codeine. In both instances, slowed passage of fluid through the gut, and thus increased contact time, could increase net absorption because a bolus of fluid was introduced into the gastrointestinal tract and then no additional fluid was infused. By contrast, in series $\mathrm{C}$, we investigated the effects of intramuscular codeine and intraluminal glucose on a steady-state model of experimental diarrhea produced by continuous total gut perfusion. In this model, mucosal cells are in contact with luminal fluid continuously, and thus contact time does not vary. Only an increase in the rate of absorption by mucosal cells could produce an increase in net absorption, and thus decrease stool volume over time. (Transient changes in stool output might result from altered motility as the gut adapts to new steady states, but this would soon be overcome by the rapid 
continuous infusion of additional test solution.) The glucose studies were done because this is a well accepted method of enhancing mucosal cell absorption rate.

The left panels of Fig. 3 show the effect of intraluminal glucose on stool output and stool PEG concentration during continuous total gut perfusion. From 0 to $5 \mathrm{~h}$, balanced electrolyte solution was infused intragastrically and stool was recovered by rectal tube. After $2 \mathrm{~h}$, steady-state conditions prevailed as indicated by more or less constant stool output and stool PEG concentration. At $5 \mathrm{~h}$, the infusate was suddenly switched to an electrolyte solution containing $100 \mathrm{mM}$ glucose. After 30-60 min, stool output declined dramatically (from an average of 1,124 to $324 \mathrm{ml} / \mathrm{h}$ ), and stool PEG marker concentrations rose (from an average of 3.6 to $9.7 \mathrm{~g} /$ liter). In contrast, as shown in the right panels of Fig. 3, when balanced electrolyte solution was infused throughout the experiment, and 30 mg codeine was given intramuscularly 4 and $5 \mathrm{~h}$ after starting the study, there was only a transient decrease in stool output with the first dose of codeine (but not after the second dose), and stool PEG concentration did not change significantly. Thus, during steady-state experimental diarrhea produced by continuous total gut perfusion, a large therapeutic dose of codeine affected neither stool output nor the rate of intestinal water absorption.

Effect of codeine on experimental diarrhea produced by colonic infusion. To determine whether the colon was the region in which codeine affected fluid movement in the nonsteady-state experimental diarrhea studies (Series A and B), we infused a bolus of $1,500 \mathrm{ml}$ of balanced electrolyte solution into the colon and then injected codeine or saline intramuscularly. Codeine had no effect on stool output (Fig. 4). In all, stool volume was $1,064 \pm 79 \mathrm{ml}$ with codeine and $1,045 \pm 42 \mathrm{ml}$ with placebo. Codeine also had no effect on the average PEG concentration in stool $(214 \pm 5$ vs. $211 \pm 8 \mathrm{mg} / \mathrm{dl}$ for codeine and placebo, respectively), or on PEG output $(2.3 \pm 0.2$ vs. $2.2 \pm 0.1 \mathrm{~g}$ for codeine and placebo, respectively). This suggests that the colon was not the site of delayed fluid movement with codeine and that codeine had no effect on the rate of water absorption by the colon.

Effect of codeine on transit time. To study further
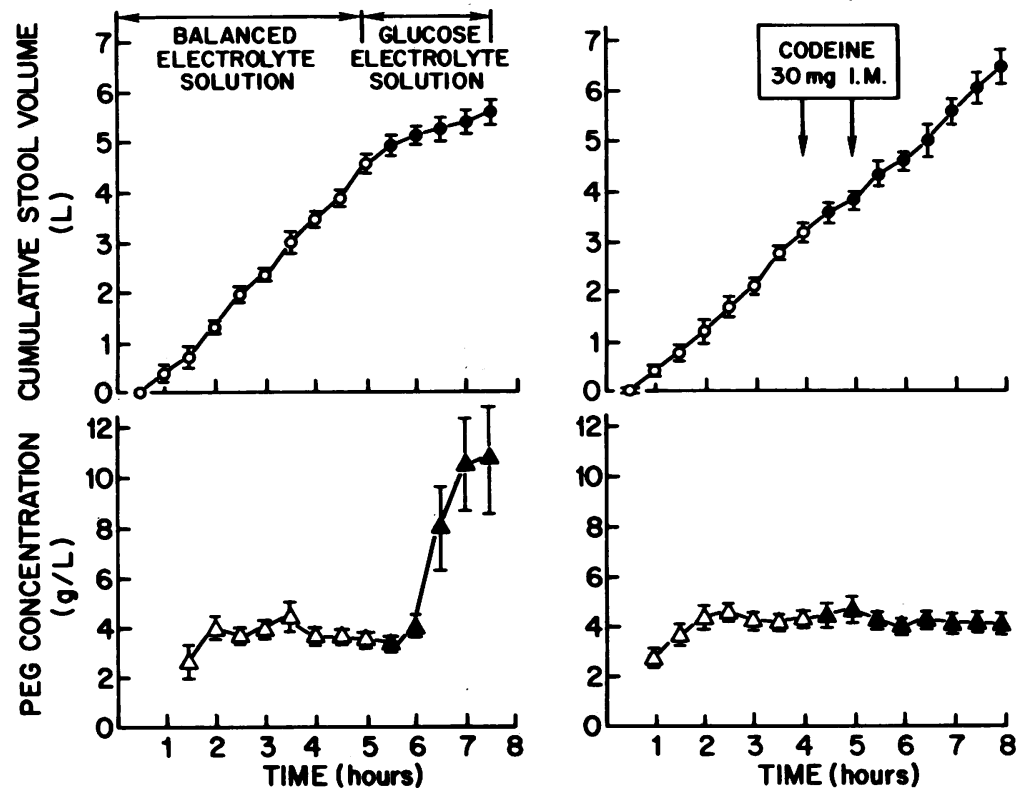

Figure 3 Series C experiments: effects of intraluminal glucose (left panels) and codeine (right panels) on experimental diarrhea induced by continuous total gut perfusion in two groups of five subjects. Cumulative stool volume (mean $\pm S E$ ) and stool PEG concentrations (mean \pm SE) are shown. In the left panels, balanced electrolyte solution containing $2 \mathrm{~g}$ PEG/liter was infused intragastrically at $30 \mathrm{ml} / \mathrm{min}$ from 0 to $5 \mathrm{~h}$, and glucose-electrolyte solution (also containing $2 \mathrm{~g} \mathrm{PEG} /$ liter) was infused from 5 to $7.5 \mathrm{~h}$. Glucose-electrolyte solution increased the rate of intestinal water absorption as indicated by the decreased stool volume and increased stool PEG concentration. In the right panels, intragastric infusion of balanced electrolyte solution was continued throughout the experiment. $30 \mathrm{mg}$ codeine was injected 4 and $5 \mathrm{~h}$ after starting the infusion (arrows). Although stool flow rate transiently decreased after codeine, PEG marker concentrations did not change significantly from precodeine levels, indicating no change in the rate of water absorption after codeine. 


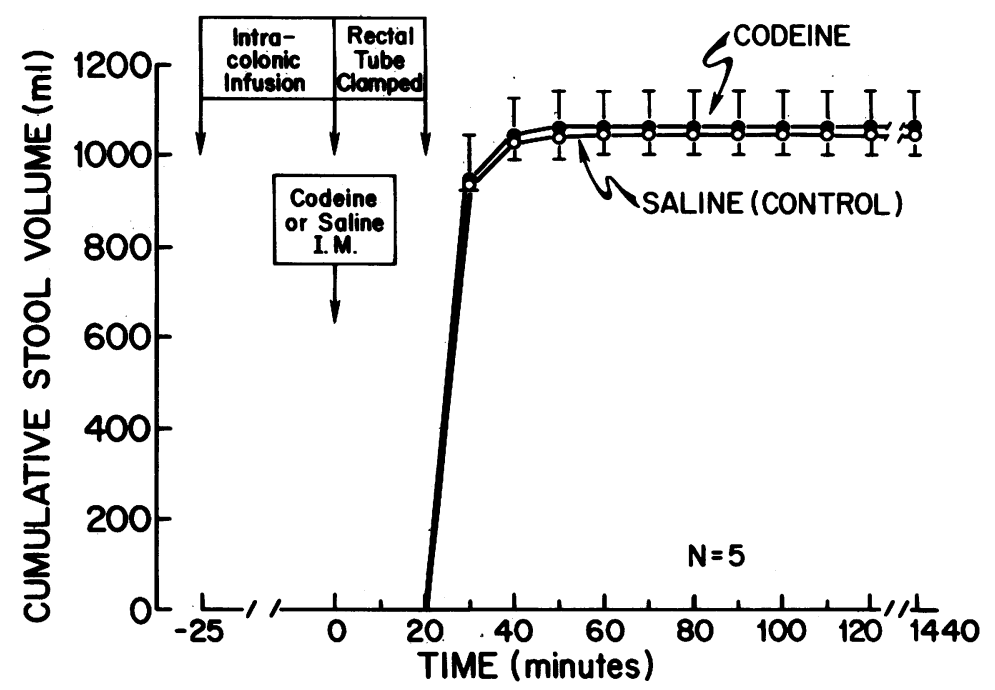

FigurE 4 Effect of codeine on experimental diarrhea: colonic infusion. After infusion of 1,500 $\mathrm{ml}$ of balanced electrolyte solution into the colon over $25 \mathrm{~min}$, the rectal infusion tube was clamped, and $30 \mathrm{mg}$ codeine or saline (control) was injected intramuscularly. 20 min later, the rectal tube was unclamped and rectal effluent was collected in 10-min samples for $100 \mathrm{~min}$. After removal of the rectal tube (at $100 \mathrm{~min}$ ), all spontaneously produced stool was collected for the remainder of a $24-h$ period. Cumulative stool volume (mean $\pm S E$ ) is plotted. None of the differences was statistically significant.

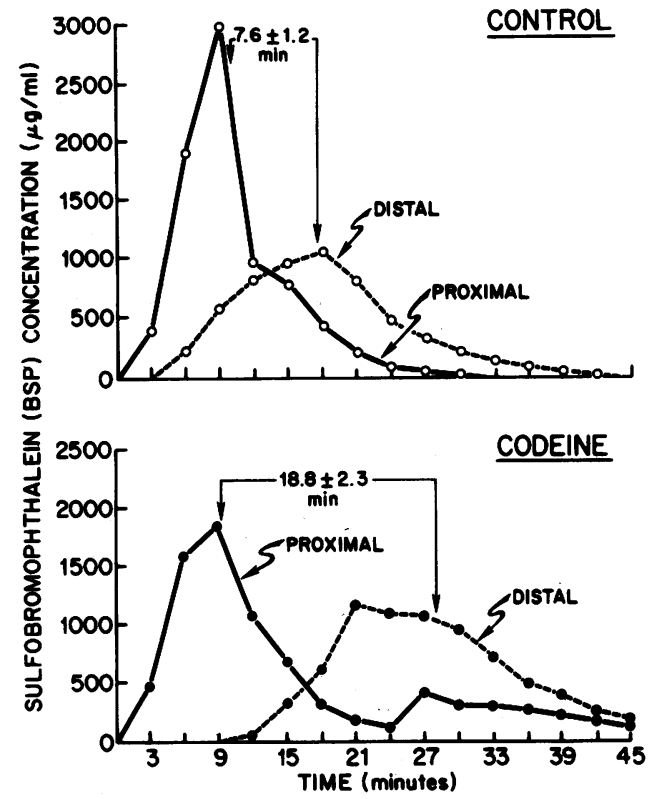

Figure 5 Jejunal dye dilution curves at proximal (solid lines) and distal (broken lines) collecting sites during steadystate perfusion studies in six subjects. The control studies are shown in the upper panel, and the studies after codeine are shown in the lower panel. A l-ml bolus containing $200 \mathrm{mg}$ of BSP was injected through the infusion site of the triplelumen tube at $0 \mathrm{~min}$. Mean transit time through the $30-\mathrm{cm}$ test segment (from proximal to distal collecting sites) was the interval between the mean appearance time of half of the BSP load at each collection site (indicated by arrows). Codeine significantly lengthened mean transit time $(P<0.01)$. the effect of codeine on fluid movement through the gut, we measured segmental transit time during steady-state intestinal perfusion. Mean transit time through the $30-\mathrm{cm}$ jejunal test segment was prolonged significantly after injection of codeine, from 7.6 \pm 1.2 to $18.8 \pm 2.3 \mathrm{~min}(P<0.01$, Fig. 5 and Table II). In contrast, transit times in the ileum and colon were unaffected by codeine (Table II). Under these steadystate conditions, mean flow rates in all regions were unchanged by codeine (Table II). Accordingly, the calculated volume of the jejunal test segment (see Methods) was more than twice as large after codeine than control $(P<0.01)$, whereas calculated ileal and colonic volumes were not affected by codeine (Table II). Thus, codeine led to retention of fluid in the proximal but not the distal gastrointestinal tract.

Effect of codeine on the rate of intestinal absorption: segmental intestinal perfusion studies. Since we failed to demonstrate any stimulation of the rate of intestinal absorption in the experimental diarrhea studies, we used segmental intestinal perfusion to measure directly the effect of codeine on the rate of intestinal absorption at various levels of gut. As shown in Table III, codeine did not significantly increase absorption rates in any region of the intestine. In fact, codeine significantly reduced the absorption rates of water, sodium, potassium, and chloride from control levels in the jejunum. The mechanism of this inhibitory effect on jejunal water and electrolyte absorption is unknown. It might reflect an actual inhibition of normal absorption or stimulation of an abnormal secretion 
TABLE II

Effect of Codeine on Mean Transit Times, Mean Flow Rates, and Intestinal Volumes in Steady-state Perfusion Studies

\begin{tabular}{|c|c|c|}
\hline & Control & Codeine \\
\hline \multicolumn{3}{|l|}{ Jejunum $(n=6)$} \\
\hline Mean transit time, $\min$ & $7.6 \pm 1.2$ & $18.8 \pm 2.3^{\circ}$ \\
\hline Mean flow rate, $\mathrm{ml} / \mathrm{min}$ & $6.6 \pm 0.4$ & $6.7 \pm 0.4$ \\
\hline Segmental volume, $\mathrm{ml} / 30 \mathrm{~cm}$ & $50.9 \pm 8.9$ & $123.2 \pm 11.3^{\circ}$ \\
\hline \multicolumn{3}{|l|}{ Ileum $(n=6)$} \\
\hline Mean transit time, $\min$ & $7.7 \pm 2.2$ & $6.9 \pm 1.5$ \\
\hline Mean flow rate, $m l / \min \ddagger$ & $8.7 \pm 0.4$ & $8.7 \pm 0.5$ \\
\hline Segmental volume, $\mathrm{ml} / 30 \mathrm{~cm}$ & $70.9 \pm 25.6$ & $61.8 \pm 15.6$ \\
\hline \multicolumn{3}{|l|}{ Colon $(n=5)$} \\
\hline Mean transit time, $\min$ & $11.3 \pm 4.5$ & $8.3 \pm 2.0$ \\
\hline Mean flow rate, $m l / \min \ddagger$ & $16.9 \pm 1.4$ & $16.6 \pm 1.5$ \\
\hline Colonic volume, $\mathrm{ml} /$ total colon & $175.8 \pm 61.5$ & $127.4 \pm 20.9$ \\
\hline
\end{tabular}

- $P<0.01$ vs. control.

I Mean flow rate is the average of the calculated flow rates at the proximal and distal collecting sites.

(16) or might be secondary to altered flow characteristics or to mechanical distention (26), since jejunal transit time and volume per unit length were greater after codeine (Table II). Xylose absorption and PD were not affected by codeine in the jejunum or ileum. (These were not measured in the colon.)

To evaluate the possibility that we could not observe any stimulatory effect of codeine in these experiments because absorption rates were already near maximal in these healthy subjects, we also examined the effect of codeine when absorption rates were reduced by intravenous infusion of VIP (17). We studied the ileum in these experiments because this was the region studied in most of the in vitro animal experiments, which suggest that opiates enhance absorption rates (1-4). On one day, saline was injected intramuscularly before and during intravenous infusion of VIP $(400 \mathrm{pmol} / \mathrm{kg}$ per $\mathrm{h}$ ). On another day, codeine (30 mg initially, followed by $10 \mathrm{mg} / \mathrm{h}$ i.m.) was injected before and during intravenous VIP infusion. As seen in Table IV, on the day when intramuscular saline was given, intravenous VIP significantly reduced water and electrolyte absorption rates in the ileum. On the day when intramuscular codeine was given, the same rate of VIP infusion reduced absorption to a similar extent. Thus, even when intestinal absorption rates were decreased by VIP, codeine did not significantly augment the rate of absorption, nor did it alter PD.

Effect of naloxone on intestinal absorption rates. If endogenous opiates have an important role in the regulation of intestinal absorption rates, infusion of naloxone, an opiate antagonist, should abolish those effects. Thus, if endogenous opiates stimulate mucosal cell absorption rates as suggested by an in vitro study (3), naloxone should reduce absorption rates. As shown in Table $\mathrm{V}$, however, this was not the case.

\section{DISCUSSION}

We found no evidence that therapeutic doses of codeine increased the rate of absorption by mucosal cells in any segment of the human intestine in vivo. The reasons for discrepancy between our findings in humans in vivo and the results of others using in vivo or in vitro animal models (1-9) are uncertain. One possibility was that intestinal absorption rates in our nor-

TABLE III

Effect of Codeine on Intestinal Transport and PD during Steady-state Perfusion Studies ${ }^{\circ}$

\begin{tabular}{|c|c|c|c|c|c|c|}
\hline & \multicolumn{2}{|c|}{ Jejunum $(n=8)$} & \multicolumn{2}{|c|}{ Ileum $(n=6)$} & \multicolumn{2}{|c|}{ Colon $(n=5)$} \\
\hline & Control & Codeine & Control & Codeine & Control & Codeine \\
\hline $\begin{array}{l}\text { Water, } \mathrm{ml} / \mathrm{h} / 30 \mathrm{~cm} \text { or } \\
\mathrm{ml} / \mathrm{h} / \text { colon }\end{array}$ & $-123+16$ & $-01+7 t$ & & & & \\
\hline Sodium, meq $/ \mathrm{h} / 30 \mathrm{~cm}$ or & $-133 \pm 10$ & $-91 \pm 1$ & $-39 \pm 12$ & $-50 \pm 25$ & $-102 \pm 24$ & $-86 \pm 20$ \\
\hline meq/h/colon & $-18.5 \pm 2.3$ & $-12.6 \pm 1.1 \downarrow$ & $-5.5 \pm 1.6$ & $-7.0 \pm 3.4$ & $-14.3 \pm 3.3$ & $-12.7 \pm 3.2$ \\
\hline $\begin{array}{l}\text { Potassium, meq } / \mathrm{h} / 30 \mathrm{~cm} \text { or } \\
\mathrm{meq} / \mathrm{h} / \mathrm{colon}\end{array}$ & $-0.5 \pm 0.1$ & $-0.3 \pm 0.1 \rrbracket$ & $-0.1 \pm 0.1$ & $-0.1 \pm 0.1$ & $+0.1 \pm 0.1$ & $0.0 \pm 0.1$ \\
\hline $\begin{array}{l}\text { Chloride, meq } / \mathrm{h} / 30 \mathrm{~cm} \text { or } \\
\mathrm{meq} / \mathrm{h} / \mathrm{colon}\end{array}$ & $-12.0 \pm 1.6$ & $-7.7 \pm 0.6 !$ & $-4.8 \pm 1.4$ & $-6.4 \pm 3.1$ & $-14.2 \pm 3.4$ & $-12.9 \pm 3.0$ \\
\hline $\begin{array}{l}\text { Bicarbonate, meq } / \mathrm{h} / 30 \mathrm{~cm} \\
\text { or } \mathrm{meq} / \mathrm{h} / \text { colon }\end{array}$ & $-7.3 \pm 1.2$ & $-5.5 \pm 0.8$ & $-0.6 \pm 0.2$ & $-0.6 \pm 0.3$ & $0.0 \pm 0.7$ & $+0.7 \pm 0.9$ \\
\hline Xylose, $m M / h / 30 \mathrm{~cm}$ & $-1.4 \pm 0.2$ & $-1.1 \pm 0.2$ & $-0.3 \pm 0.1$ & $-0.3 \pm 0.1$ & ND & ND \\
\hline PD, $m V$ & $-3.0 \pm 1.1$ & $-3.0 \pm 1.1$ & $-6.6 \pm 1.8$ & $-6.7 \pm 1.9$ & ND & ND \\
\hline
\end{tabular}

- Results are expressed as mean $\pm \mathrm{SE}$. Except for PD (lumen negative), negative signs indicate absorption and positive signs indicate secretion. ND indicates measurement not done (see text).

$f P<0.05$ vs. control. 
TABLE IV

Effect of VIP on Water and Electrolyte Absorption in the Ileum with and without Codeine in Six Normal Subjects ${ }^{\circ}$

\begin{tabular}{|c|c|c|c|c|c|c|}
\hline & \multicolumn{3}{|c|}{ Saline } & \multicolumn{3}{|c|}{ Codeine } \\
\hline & Control & VIP & $\Delta \mathfrak{q}$ & Control & VIP & $\Delta \mathfrak{t}$ \\
\hline $\begin{array}{l}\text { Water absorption, } \\
\mathrm{ml} / \mathrm{h} / 30 \mathrm{~cm}\end{array}$ & $68 \pm 18$ & $32 \pm 11 \S$ & $37 \pm 11$ & $84 \pm 15$ & $34 \pm 6 \S$ & $50 \pm 11$ \\
\hline $\begin{array}{l}\text { Sodium absorption, } \\
m e q / \mathrm{h} / 30 \mathrm{~cm}\end{array}$ & $9.6 \pm 2.5$ & $4.5 \pm 1.6 \S$ & $5.1 \pm 1.1$ & $11.6 \pm 2.0$ & $4.6 \pm 0.8 \S$ & $6.9 \pm 1.5$ \\
\hline $\begin{array}{c}\text { Chloride absorption, } \\
m e q / h / 30 \mathrm{~cm}\end{array}$ & $8.2 \pm 2.1$ & $4.2 \pm 0.5 \S$ & $4.0 \pm 1.4$ & $10.2 \pm 1.7$ & $4.3 \pm 0.6 \S$ & $5.8 \pm 1.3$ \\
\hline $\begin{array}{l}\text { Bicarbonate absorption, } \\
m e q / h / 30 \mathrm{~cm} \\
\mathrm{PD}^{\| l} \mathrm{mV}\end{array}$ & $\begin{array}{r}2.0 \pm 0.7 \\
-6.5 \pm 0.8\end{array}$ & $\begin{array}{l}0.1 \pm 0.2 \S \\
-6.8 \pm 0.8\end{array}$ & $\begin{array}{l}2.0 \pm 0.6 \\
0.1 \pm 0.6\end{array}$ & $\begin{array}{r}1.6 \pm 0.6 \\
-4.9 \pm 0.4\end{array}$ & $\begin{array}{l}0.1 \pm 0.2 \S \\
-5.2 \pm 1.2\end{array}$ & $\begin{array}{l}1.5 \pm 0.4 \\
0.6 \pm 0.6\end{array}$ \\
\hline
\end{tabular}

- Each subject received an intramuscular injection of saline or codeine ( $30 \mathrm{mg}) 30 \mathrm{~min}$ before the start of the control hour. Reinforcing injections of saline or codeine $(10 \mathrm{mg})$ were then given hourly until the conclusion of the experiment. On another day, subjects received the other injection (codeine or saline). VIP was infused at a rate of $400 \mathrm{pmol} / \mathrm{kg}$ per h throughout the second half of each experiment. $\downarrow$ The reduction in absorption rate (or change in PD) with VIP $(\Delta)$ was not significantly different with or without codeine.

$\S P<0.05$ vs. control.

" $(-)$ indicates lumen-negative PD.

mal human subjects might have been at or near maximal levels already, precluding observation of any stimulation of absorption by codeine. To test this possibility, we reduced intestinal absorption rates by infusing the antiabsorptive agent, VIP (20). We found that codeine did not reverse, even partially, the antiabsorptive effect of VIP. Thus, we could not demonstrate that codeine stimulated absorption rates in humans even when absorption rates were definitely submaximal.

Another explanation for the discrepancy between this study and the others may be the dose of opiate used. In our studies, we detected an antidiarrheal effect with therapeutic doses of codeine and investigated the mechanism of this effect with these same doses. In vitro studies with codeine or morphine $(1,2,4)$ used doses that were relatively much higher. For instance, one in vitro study of intestinal ion transport examined the effect of $1 \mathrm{mM}$ codeine. This corresponds to a dose in humans of roughly $7 \mathrm{~g}$ of codeine, more than 120 times the therapeutic dose used in our studies. (The molecular weight of codeine phosphate is 424 . If one assumes a volume of distribution equal to the extracellular fluid volume [ $\sim 17$ liter in an adult], $7.2 \mathrm{~g}$

TABLE V Effect of Naloxone on Water and Electrolyte Absorption in Jejunum and Ileum ${ }^{\circ}$

\begin{tabular}{|c|c|c|c|c|}
\hline & \multicolumn{2}{|c|}{ Jejunum $(n=10)$} & \multicolumn{2}{|c|}{ Ileum $(n=5)$} \\
\hline & Control & Naloxone & Control & Naloxone \\
\hline $\begin{array}{l}\text { Net water absorption, } \\
\mathrm{ml} / \mathrm{h} / 30 \mathrm{~cm}\end{array}$ & $98 \pm 15$ & $125 \pm 24$ & $39 \pm 12$ & $39 \pm 7$ \\
\hline $\begin{array}{l}\text { Net sodium absorption, } \\
\mathrm{meq} / \mathrm{h} / 30 \mathrm{~cm}\end{array}$ & $13.3 \pm 2.1$ & $17.2 \pm 3.3$ & $5.3 \pm 1.9$ & $5.2 \pm 1.0$ \\
\hline $\begin{array}{l}\text { Net potassium absorption, } \\
m e q / \mathrm{h} / 30 \mathrm{~cm}\end{array}$ & $0.4 \pm 0.1$ & $0.5 \pm 0.2$ & $0.0 \pm 0.1$ & $0.0 \pm 0.1$ \\
\hline $\begin{array}{l}\text { Net chloride absorption, } \\
m e q / \mathrm{h} / 30 \mathrm{~cm}\end{array}$ & $6.8 \pm 1.6$ & $10.2 \pm 2.9$ & $5.1 \pm 1.3$ & $4.7 \pm 0.7$ \\
\hline $\begin{array}{l}\text { Net bicarbonate absorption, } \\
m e q / h / 30 \mathrm{~cm}\end{array}$ & $6.7 \pm 0.6$ & $7.5 \pm 0.6$ & $0.1 \pm 0.4$ & $0.1 \pm 0.4$ \\
\hline$P D \downarrow, m V$ & $-4.1 \pm 0.6$ & $-4.1 \pm 0.4$ & $-7.6 \pm 1.1$ & $-7.7 \pm 1.2$ \\
\hline
\end{tabular}

- Differences between control and naloxone were not statistically significant in either the jejunum or ileum.

$\ddagger(-)$ indicates lumen-negative PD. 
would have to be administered to yield a concentration of $1 \mathrm{mM}$.)

Differences in the specific opiates tested may also be important. There are thought to be four different types of opiate receptors with different affinities for agonists and antagonists $(1,27,28)$. Codeine and morphine interact with the mu-receptor, whereas enkephalins and enkephalin analogues interact with the delta-receptor. Delta-receptor agonists appear to be more potent stimulants of mucosal absorption in vitro than mu-receptor agonists $(1,4)$. It is conceivable that opiate agents with great affinity for the delta-receptor might prove to be effective antidiarrheal agents by virtue of the stimulation of the rate of absorption by mucosal cells, but such agents have yet to be developed for use in humans. Currently available opiate antidiarrheal drugs, such as codeine, diphenoxylate, and loperamide, are thought to be mu-receptor agonists.

In addition to studies with codeine, we also investigated the effects of naloxone, an opiate antagonist, on intestinal absorption rates. If endogenous opiates (i.e., enkephalins or endorphins) regulate (i.e., enhance) intestinal absorption in man as suggested by some studies (1-4), then blockade of opiate receptors with naloxone should reduce absorption rates. However, administration of a large dose of naloxone, in a dose that significantly reduces gastric acid secretion (21) and that blocks the gastric effects of a large dose of loperamide (22), produced no significant changes in jejunal or ileal absorption rates. This casts some doubt on the concept that endogenous opiates have a role in the regulation of intestinal absorption rates in humans.

Our results suggest that codeine reduces stool volumes in subjects with nonsteady-state experimental diarrhea by an effect on the movement of fluid through the proximal small intestine. As a result of an effect on jejunal motility, codeine causes retention of luminal contents in the proximal gastrointestinal tract and thus slows the delivery of fluid from proximal to distal sites in the intestine. Retention of fluid proximally and slower delivery of fluid from proximal to distal sites increases the contact time of a given volume of fluid with the intestinal mucosa, and thus allows for more complete absorption of luminal contents and reduction in stool volume.

Codeine may have a similar antidiarrheal effect in patients with many diarrheal diseases. Such actions might be especially important after a meal, when a 2-3-liter bolus of ingested food and secretions is presented to the intestine (29). The schema described above might also explain the antidiarrheal effect of codeine in patients with diarrhea due to colonic disease, even though codeine appears to have no effect on fluid propulsion in the colon itself. For example, increased contact time in the small intestine might lead to the delivery of subnormal volumes of fluid to the diseased colon, and this might result in a decrease in stool volume. A similar mechanism might also account for constipation in patients treated with opiates for indications other than diarrhea. Obviously, opiates may have other effects which may be beneficial to patients with diarrhea, such as relief of pain or tenesmus; however, these other effects were not assessed by our studies.

The mechanism described above could reduce stool output only in nonsteady-state situations, when boluses of fluid traverse the gut, and slower movement of luminal fluid can increase the time available for mucosal cells to absorb luminal fluid. By contrast, during steady-state perfusion at high flow rates, all of the intestinal mucosa is continuously exposed to luminal fluid and changes in intestinal tone and transit time cannot increase the exposure of absorbing mucosal cells to luminal fluid because it is already maximal. It is probably for this reason that codeine had no effect on experimental diarrhea produced by continuous and rapid intragastric infusion of balanced electrolyte solution (series $\mathrm{C}$ studies), where stool volumes averaged $\sim 800 \mathrm{ml} / \mathrm{h}$. On the basis of this experimental model, it seems unlikely that codeine would reduce stool volume in patients with very severe diarrhea where all parts of the intestine are continuously exposed to large volumes of fluid (a situation analogous to our series C studies).

\section{ACKNOWLEDGMENTS}

The authors express their appreciation to Ms. Jean Harber and Ms. Vicky Usry for their excellent assistance in preparation of this manuscript.

This work was supported by U. S. Public Health Service grant 1-R01-AM26794 from the National Institute of Arthritis, Metabolism and Digestive Diseases, and the Southwestern Medical Foundation's Abbie K. Dreyfuss Fund, Dallas, Texas.

\section{REFERENCES}

1. Kachur, J. F., R. J. Miller, and M. Field. 1980. Control of guinea pig intestinal electrolyte secretion by a deltaopiate receptor. Proc. Natl. Acad. Sci. U.S.A. 77: 27532756.

2. Racusen, L. C., H. J. Binder, and J. W. Dobbins. 1978. Effects of exogenous and endogenous opiate compounds on ion transport in rabbit ileum in vitro. Gastroenterology. 74: 1081 .

3. Dobbins, J., L. Racusen, and H. J. Binder. 1980. Effect of D-alanine methionine enkephalin amide on ion transport in rabbit ileum. J. Clin. Invest. 66: 19-28.

4. McKay, J. S., B. D. Linaker, and L. A. Turnberg. 1981. Influence of opiates on ion transport across rabbit ileal mucosa. Gastroenterology. 80: 279-284.

5. Karim, S. M. M., and P. G. Adaikan. 1977. The effect of loperamide on prostaglandin induced diarrhea in rat and man. Prostaglandins. 13: 321-331.

6. Coupar, I. M. 1978. Inhibition by morphine of prosta- 
glandin-stimulated fluid secretion in rat jejunum. Br. J. Pharmacol. 63: 57-63.

7. Beubler, E., and F. Lembeck, 1979. Inhibition of stimulated fluid secretion in the rat small and large intestine by opiate agonists. Naunyn-Schmiedeberg's Arch. Pharmacol. 306: 113-118.

8. Lembeck, F., and E. Beubler. 1979. Inhibition of PGE - $^{-}$ induced intestinal secretion by the synthetic enkephalin analogue FK 33-824. Naunyn-Schmiedeberg's Arch. Pharmacol. 308: 261-264.

9. Sandhu, B. K., J. H. Tripp, D. C. A. Candy, and J. T. Harries. 1981. Loperamide: studies on its mechanism of action. Gut. 22: 658-662.

10. Powell, D. W. 1981. Muscle or mucosa: the site of action of antidiarrheal opiates? Gastroenterology. 80: 406-408.

11.. Jaffe, J. H., and W. R. Martin. 1980. Opioid analgesics and antagonists. In The Pharmacological Basis of Therapeutics. L. S. Goodman and A. Gilman, editors. MacMillan, Inc., New York. Chapter 22, 6th edition. 494-534.

12. Shee, C. D., and R. E. Pounder. 1980. Loperamide, diphenoxylate and codeine phosphate in chronic diarrhoea. Br. Med. J. 1: 524 .

13. Palmer, K. B, C. L. Corbett, and C. D. Holdsworth. 1980. Double-blind crossover study comparing loperamide, codeine and diphenoxylate in the treatment of chronic diarrhea. Gastroenterology. 79: 1272-1275.

14. Davis, G. R., C. A. Santa Ana, S. G. Morawski, and J. S. Fordtran. 1980. Development of a lavage solution associated with minimal water and electrolyte absorption or secretion. Gastroenterology. 78: 991-995.

15. Fordtran, J. S. 1966. Marker perfusion techniques for measuring intestinal absorption in man. Gastroenterology. 51: 1089-1093.

16. Fordtran, J. S., F. S. Rector, Jr., and N. W. Carter. 1968. The mechanisms of sodium absorption in the human small intestine. J. Clin. Invest. 47: 884-900.

17. Dillard, R. L., H. Eastman, and J. S. Fordtran. 1965. Volume-flow relationship during the transport of fluid through the human small intestine. Gastroenterology. 49: 58-66.
18. Fordtran, J. S., F. C. Rector, Jr., M. F. Ewton, N. Soter, and J. Kinney. 1965. Permeability characteristics of the human small intestine. J. Clin. Invest. 66: 1326-1333.

19. Davis, G. R., C. A. Santa Ana, S. G. Morawski, and J. S. Fordtran. 1980. Active chloride secretion in the normal human jejunum. J. Clin. Invest. 66: 1326-1333.

20. Davis, G. R., C. A. Santa Ana, S. G. Morawski, and J. S. Fordtran. 1981. Effect of vasoactive intestinal polypeptide on active and passive transport in human jejunum. J. Clin. Invest. 67: 1687-1694.

21. Feldman, M., J. H. Walsh, and I. L. Taylor. 1980. Effect of naloxone and morphine on gastric acid secretion and on serum gastrin and pancreatic polypeptide concentrations in humans. Gastroenterology. 79: 294-298.

22. Caldara, R., M. Cambielli, E. Masci, M. Guslandi, C. Barbieri, and C. Ferrari. 1981. Effect of loperamide and naloxone on gastric acid secretion in healthy man. Gut. 22: 720-723.

23. Hyden, S. 1955. A turbidometric method for the determination of higher polyethylene glycols in biological materials. Lantbrukshogsk. Ann. 22: 139-145.

24. Roe, H., and E. W. Rice. 1948. Photometric method for determination of pentoses in animal tissues. J. Biol. Chem. 173: 507-512.

25. Colton, T. 1974. Statistics in Medicine. Little, Brown and Co., Boston

26. Caren, J. F., J. H. Meyer, and M. I. Grossman. 1974. Canine intestinal secretion during and after rapid distention of the small bowel. Am. J. Physiol. 227: 183188.

27. Martin, W. R., C. G. Eades, J. A. Thompson, R. E. Huppler, and P. E. Gilbert. 1976. The effects of morphine and nalorphrine-like drugs in the nondependent and morphine-dependent chronic spinal dog. J. Pharmacol. Exp. Ther. 197: 517-532.

28. Lord, J. A. H., A. A. Waterfield, J. Hughes, and H. W. Kosterlitz. 1977. Endogenous opioid peptides: multiple agonists and receptors. Nature (Lond.). 267: 495-499.

29. Fordtran, J. S., and T. M. Locklear. 1966. Ion constituents and osmolality of gastric and small intestinal fluids after eating. Am. J. Dig. Dis. 11: 503-521. 